European Journal of Accounting, Auditing and Finance Research

Vol.10, No. 1, pp.25-54, 2022

Print ISSN: 2053-4086(Print),

Online ISSN: 2053-4094(Online)

\title{
DETERMINANTS OF TECHNOLOGICAL INNOVATION ADOPTION AND BANKING OPERATIONS OF SELECTED DEPOSIT MONEY BANKS IN NIGERIA
}

\author{
${ }^{1}$ Salami, Saheed Olawale \\ Department of Finance, School of Management Sciences, Babcock University \\ Ilishan-Remo, Ogun State, Nigeria \\ ${ }^{2}$ Akande, Folorunso I. (Ph.D) \\ Department of Finance, School of Management Sciences, Babcock University \\ Ilishan-Remo, Ogun State, Nigeria \\ ${ }^{3}$ Alalade, Y.S.A (Ph.D) \\ Department of Finance, School of Management Sciences, Babcock University \\ Ilishan-Remo, Ogun State, Nigeria
}

\begin{abstract}
Banks are one the most important financial institutions that contribute efficiently to the growth of any economy. The banking institutions have contributed significantly to the effectiveness of the entire financial system as they offer an efficient institutional mechanism through which resources can be mobilized and directed from less essential uses to more productive investment; yet, there have been challenges confronting deposit money banks in Nigeria in form of governance process control, risk management, compliance and consulting, financial reporting and fraud audit. Therefore, the study examined the determinants of technological innovation adoptions and their effects on banking operations of deposit money banks in Lagos, Nigeria.The research designs adopted for this study was survey research design. The target population used for this study was employees of the selected deposit money banks in Lagos State, Nigeria. The sample size for the study is 397 and simple random sampling technique was adopted for the study. The research instrument was questionnaire which was validated by the supervisor and the reliability was 0.843. The data for the study was analyzed using simple regression analysis.The study showed that technological innovations have significant effects on banking operations in selected deposit money banks in Lagos State, Nigeria. The finding also revealed that ease of use has significant effect on operational efficiency of deposit money banks in Lagos, Nigeria with Adj $R^{2}=0.698 ;$ F-Statistic $(d f=4,432)=190.224$ and $p$-value $=0.000$. The study revealed that compatibility has significant effect on operational structure of deposit money banks in Lagos, Nigeria with Adj $R^{2}=0.556 ; F$-Statistics $(d f=4,432) .=499.656$ and $p$-value $=0.000$. The study concludes that investment in technology will bring an improvement in the operations of deposit money banks in Nigeria. It is however recommended that the government through CBN should provide adequate security measures towards the various e-banking products in Nigeria. This will aid in reducing the rate of fraud and forgery in the banking industry and encourage investors which in turn will increase the banks' cash inflow cum use of available fund for granting of credit facilities.
\end{abstract}

KEYWORDS: compatibility, customer relationship, ease of use, operational efficiency, operational structure.

ECRTD-UK: https://www.eajournals.org/

ULR: https://doi.org/10.37745/ejaafr.2013 


\section{INTRODUCTION}

An efficient banking operation contributes to the stability, sustainability and financial inclusion drive of Deposit Money Banks in Nigeria. However, despite efforts pulled together by monetary authorities to enhance a seamless banking operation through technological innovations in the banking sector, Deposit Money Banks continue to experience low operational efficiencies occasioned by incessant network failures, system downtime, financial illiteracy, electronic fraud, and transaction errors.

Banking operations involve the practices and procedures that a bank uses to ensure that customers' transactions are completed accurately and appropriately. This involves the mechanism employed by the banks to ensure an effective payment system at all times. Also, banking operations comprise of the process put in place by the bank in protecting its clientele from any potential threats to the client's finances. Generally, banking operations cover the legal transactions executed by a bank in its daily business, such as providing loans, mortgages and investments (Sahem, 2015).

Banks are one the most important financial institutions that contribute efficiently to the growth of any economy (Adegbie \& Dada, 2018). They are institutions for sourcing funds, often made from the surplus sector and transfer same to develop the deficit sector of the same economy known as the principal financial bedrock of the economy. Ssekiziyivu, Mwesigwa, Joseph and Nkote (2017); Bananuka, Tumwebaze and Orobia (2018); Nalukenge, Nkundabanyanga and Ntayi (2018); Kabuye, Kato, Akugizibwe and Bugambiro (2019); among other studies had examined the relationship between technological innovation and banking operation in different countries in the world. It was observed that there are limited studies that focus on banking operation from the context of technological innovation adoptions. Banking institutions have contributed significantly to the effectiveness of the entire financial system as they offer an efficient institutional mechanism through which resources can be mobilized and directed from less essential uses to more productive investment. There have been challenges confronting deposit money banks in Nigeria. Some of these challenges are lack of sufficient deposits to meet banks service demands, governance process control, risk management, compliance and consulting, financial reporting and fraud audit are some of the issues requiring management attention of banks. Also, non-compliance with various Central Bank monetary policies regarding cash reserve requirements to meet their daily operations, poor liquidity management of assets and liquidity mismatch are major challenges facing the banking institutions.

In countries like the United States of America, Japan, United Kingdom and other European countries especially in this 21 st century, the banking industry operates in a complex and competitive environment characterized by changing conditions and highly unpredictable economic climate with Information and Communication Technology (ICT) at the center of the change curve. In the global world, the core operation requires digitization to provide innovative services so as to survive in the dynamic business environment. According to Yaw and Boachie (2018), banks are

ECRTD-UK: https://www.eajournals.org/

ULR: https://doi.org/10.37745/ejaafr.2013 
leveraging trends in information technology to pursue technological innovation (product and process innovation) which enhances improvements in service delivery methods operational efficiency, and reducing the turnaround of transactions.

In Africa, there has been persistent public outcry as regards the challenges in electronic banking since its inception in 1996. To many people, banking transactions via the internet are insecure and often congested. Hence, interruption is usually experienced in banking operations due to network failures; this hinders customers from carrying out transactions seamlessly at that point in time. Besides, many people do not know what e-banking entails, or how to use its products. This aids in revealing the secrete PIN number (in the case of ATM card and other cards transaction) to the third party by the illiterate cardholders(customers) at any time they want to make withdrawals as they always request for assistance. Consequently, there are increase cases of fraudulent activities in the banking industry (Obasan, 2011). The CBN Annual Report and Statement of Accounts (2009) have it that, the number of reported cases of attempted or successful fraud and forgery in the banking industry rose in 2009. According to the report, seventy percent of the fraud cases were perpetrated via the electronic system. Therefore, the continuous increase in the cases of reported fraud has posed problems to the smooth operations of electronic banking in Nigeria.

In Nigeria according to Yinus and Waidi (2011), technology innovation has influenced the performance of all Nigerian banks. In the last ten years' tremendous achievements were achieved in banks networking, service delivery, profitability and customer's responses. Technological advancement facilitates payments and creates convenient alternatives to cash and cheque for making transactions. This new practices and innovations have led to the development of a truly global, seamless and Internet enabled 24-hour banking operations (Obasan, 2011).

Technological innovation is neither a single event nor even a small number of discrete events. It involves rich embroidery of events, many activities, many decisions, and many bits of behavior on the part of individuals and social units, most of whom are not even self-consciously aware of being part of such a process. The evolving technological innovation in banks has seen the introduction of electronic banking systems over internet platforms, the introduction of mobile banking systems, online funds transfers and transactions. Also, most banks collaborate with telecommunication companies to provide banking services via the Internet and mobile phones, which they hope will help them gain sustainable competitive advantage (Akerlof \& Girardone, 2011). Technological developments have created new delivery channels for banking products and services, such as Automated Teller Machines (ATMs), Internet banking, Point of Sales (POS), Unstructured Supplementary Service Data (USSD) and mobile banking. Over the years, these innovations have grown tremendously.

The link between technological innovation and banking operations can be found in increased number of customers, increased transactions, increased efficiency, quality and profitability (Ngugi \& Karina, 2013). Similarly, Drucker (2013) noted that technological innovation increases competitive advantage since banks are able to utilize technology to enhance efficiency and quality.

ECRTD-UK: https://www.eajournals.org/

ULR: https://doi.org/10.37745/ejaafr.2013 
Also, Khalil (2012) stated that technology helps in planning, scheduling, and service production which are components of operational management. Research in this area in Nigeria has focused attention majorly on technological innovation and financial performance of deposit money banks. However, research on the determinants of technological innovation adoption and banking operations of deposit money banks in Nigeria has not been adequately populated in the literature unlike other emerging economies. In order to fill this important gap in the literature, this study examined the determinants of technological innovation adoption and banking operation of deposit money banks in Nigeria.

Despite efforts pooled together by monetary authorities to enhance seamless banking operations in financial institutions, Nigerian banking sector continues to experience low operational efficiencies, slow service delivery, customer dissatisfaction, high turn-around time on transactions, network failures, and incessant transaction errors. Crytonn (2016) argued that many banks in Nigeria are making huge investments in technology to maintain and upgrade their infrastructure in order to improve banking operations and customers' satisfaction. Certainly, these developments may ultimately change the competitive landscape in the financial services. However, the downside of these innovations is that it increases significant stress on operations of the bank, particularly planning, scheduling, efficiency, effectiveness, quality and staffing across the areas of bank operations. If this view is to be accepted, it therefore, presupposes that an efficient banking operation enhances the stability, sustainability and financial inclusion drive of Deposit Money Banks in Nigeria.

Theories like, Silber's constraint of innovation and diffusion of innovation theory have shown that technological innovation adoptions are key factors that enhance banking operations of deposit money banks, it is therefore imperative to examine the determinants of technological innovation adoptions and their effect on banking operations. However, empirical studies replicating these theories on the determinants of technological innovation adoption and banking operations of deposit money banks is at low studies in Nigeria as majority of the studies examined the effect of technological innovations on financial performance of deposit money banks. Therefore there is a need to examine the determinants of technological innovation adoption and its resultant effect on banking operations of deposit money banks in Nigeria.

\section{Objectives of the Study}

To determine the impact of ease of use of technological innovations on operational efficiency of deposit money banks in Lagos, Nigeria.

To examine the effect of compatibility of technological innovations on operational structure of deposit money banks in Lagos, Nigeria.

\section{Research Questions}

How does ease of use of technological innovation affect operational efficiency of deposit money banks in Lagos, Nigeria?

ECRTD-UK: https://www.eajournals.org/

ULR: https://doi.org/10.37745/ejaafr.2013 
How does compatibility of technological innovation affect operational structure of deposit money banks in Lagos, Nigeria?

\section{Hypotheses}

$\mathrm{H}_{01}$. Ease of use has no significant effect on operational efficiency of deposit money banks in Lagos, Nigeria.

$\mathrm{H}_{02}$. Compatibility has no significant effect on operational structure of deposit money banks in Lagos, Nigeria.

\section{REVIEW OF RELATED LITERATURE}

\section{Technological Innovations}

Cumming (2008) opined that technological innovation comprises of systems innovation, processes innovation and equipment employed in an organization to drive and ensure seamless operational activities. The author further defined process innovation as the process of reengineering and improving internal operation of business process. This process involves aspects of a firm's function such as technical design, $\mathrm{R} \& \mathrm{D}$, manufacturing, commercial activities and management. According to Oke and Goffin (2011), process innovation involves the development and enhancement of techniques geared towards enhancement of operational activities and service quality. For example, innovation in skill, techniques, technology, system and procedure, which is used in the transformation process of input into output.

Drucker (2013) noted that innovations provide firms with a strategic orientation to overcome the problems they encounter while they strive to attain sustainable competitive advantage. Innovation involves acting on the creative ideas to make some specific and tangible difference in the domain in which the innovation occurs (Davila, 2010). Recent developments include leveraging the advancements in information technology to develop new or significantly improved products and/or processes (IT technological innovation) (OECD, 2005). Other goals include driving human capital development (Obeng \& Mkhize, 2017), attaining operational efficiency and service quality (Parasuraman, 2010), and improving customer expectations (Chen, 2005). In contemporary service organizations, innovation is a core competency. Damanpour (2010) and OECD (2005) classified technological innovations into process and product innovations. For product innovation, new or significantly improved products are developed to improve customer service and capture new markets (Damanpour, 2010).

\section{Perceived Ease of Use (PEU)}

Perceived ease of use (PEU) describes the extent to which innovative E-banking products are easy to understand and operate. Innovations which customers perceive as difficult to understand may be underutilized, since they would require much time and effort to master. Black (2001) noted that innovations which customers perceive as complex will take a lot of time to be adopted by the customers. In other words, perceived ease of use in technological innovation is expected to have a positive influence on acceptability. Similarly, Eriksson (2008) established that the perceived ease

ECRTD-UK: https://www.eajournals.org/

ULR: https://doi.org/10.37745/ejaafr.2013 
of use of innovative banking products positively influences customer adoption and acceptability of such technological innovations.

\section{Compatibility}

Compatibility is the degree to which an innovation is perceived as consistent with the existing values, past experiences, and needs of potential users. Rogers (2003) emphasized that an innovation which is incompatible with an individual's needs may negatively affect such individuals innovation acceptability. Vijayasarathy (2004) observes that compatibility is one of the best perception-based indicators of attitudes towards the adoption of online innovation, if an innovation is compatible with an individual's needs, then uncertainty will decrease and the rate of acceptability will increase. In Singapore, Gerrard and Cumming (2008) examined the factors affecting the adoption of e-banking innovations. Their study identified eight characteristics which influence the rate of adoption, among which is compatibility as an innovation attribute which influences the adoption of e-banking innovations such as Internet and mobile banking.

\section{Banking Operations}

Banking operations involve the practices and procedures that a bank uses to ensure that customers' transactions are completed accurately and appropriately. For example, if a customer wishes to purchase stock or shares, the bank ensures that the money and the stock are ready to be traded. The bank will oversee the actual transfer of the stock and funds, and it will ensure that any reporting requirements regarding the transaction are recorded. Throughout the process, the bank focuses on protecting its clientele and looking for any potential threats to the client's finances.

In general, many people are most familiar with retail banking. Retail banking provides services to the general public, including mortgages, loans, deposits, and current accounts. Since these banks serve the general population, the market is highly competitive. To build a customer base, most of the banks focus on providing highly convenient and accessible services to their clientele. Once a customer enlists a bank to provide a certain service, such as a current account, the banks will typically then encourage the client to open a savings account as well. Internal banking operations at a retail bank involve opening new accounts, transferring money between accounts, and assisting customers with managing deposits (Casu, Girardone, \& Molyneux, 2006).

Also, corporate banking is another common banking operation. Overall, business banks function very similarly to retail banks, except that their clientele consists primarily of businesses. Companies require a wide variety of banking services, including start-up loans, collecting deposits, and investments. Due to the complexities of many businesses, corporate banking is often more complex and sophisticated than retail banking. Companies often rely on banks for treasury functions, including managing the business' accounts receivable and payable.

\section{Operational Efficiency}

Operational efficiency is simply defined as the ability to deliver products and service cost effectively without sacrificing quality. Shawk (2008) defined operational efficiency as what occurs

ECRTD-UK: https://www.eajournals.org/

ULR: https://doi.org/10.37745/ejaafr.2013 
when a right combination of people, process and technology come together to enhance the productivity and value of any business operation, while driving down the cost of routine operations to a desired level. According to Levine (2000), Efficiency in intermediation of funds from savers to borrowers enables allocation of resources to their most productive users. The more efficient a financial system is in such resource generation and in its allocation, the greater its contribution to productivity and economic growth.

Generally, operational efficiency refers to the efficient utilization of human and material resources or the efficient use of people, machines, financial resources, tools and equipment. Better utilization of any or a combination of these, can increase output of goods and services and reduce costs. Operational efficiency is the tactical planning of an organization to keep a healthy balance between cost and productivity. It identifies the wasteful processes that contribute to drainage of resources and organizational profits. It deals with minimizing waste and maximizing the benefits of resource to provide better services to the customers. To face tough competition lowering costs is a best option as internal wastage contributes to high cost of operation. Technical efficiency is the major criteria for measuring efficacy of banks (Shawk, 2008).

In the light of various banking sector reforms \& developments as well as apparent challenges in the Nigeria banking Industry, it is interesting to know whether the banks have efficiently performed or not and what are the parameters of the efficiency measurement. The word operational efficiency in a general concept and is purely a developmental tool applied to a part or to all of the conduct of activities of a banking business over a period of time. It is used to measure the efforts extended to achieve the targets efficiently and effectively. The achievement of targets involves the integrated use of human, financial and reference to past or projected technical efficiency, management responsibility and accountability. It also reflects the quality in terms of growth, performance and results achieved by the management of deposit money banks.

\section{THEORETICAL REVIEW}

\section{Silber's Constraint Theory of Innovation}

This theory was coined by Silber in 1975 with the aim of describing the reasons of financial innovation in financial institutions. The concept of constraint theory of innovation is based on the notion that financial innovation enhances profitability of firms through efficiency of delivery of services. The theory views that banks have both internal and external constraints which can be managed through adoption of technologically enabled process. Therefore, through harnessing the power of technology, banks can enhance efficiency which in turn leads to cost reduction (Gakure \& Ngumi, 2013).

This theory is based on the assumption that technological innovations in financial service industry tend to attract more customers to banks product which also saves the bank in huge administrative cost. This implies that technological innovations are in two folds; one it serves as a means of saving cost for financial institutions and secondly it is a tool for market and product development.

ECRTD-UK: https://www.eajournals.org/

ULR: https://doi.org/10.37745/ejaafr.2013 
In support of Silber's Constraint Theory of Innovation, Gakure and Ngumi (2013) noted that banks that were not innovative had poor performance when compared with banks that engaged in product development through technological innovations, this implies that technological innovations drive banks performance and operational efficiency.

Husein (2013) criticized this theory and noted that Silber's constraint theory of innovation focused attention majorly on the benefits of technological innovations to financial institutions rather than the advantages of such innovations in the aspect of service quality and customer relationship. This theory is important to this study as it provides an alternative explanation suggesting that operational constraints in the banking environment can be curbed through robust and effective technological innovation. The theory is thus applicable in this study since it postulates that technological innovations enhance the operational performance of financial institutions.

\section{Financial Intermediation Theory}

The financial intermediation theory was developed by Leland and Pyle in 1977. The theory emphasized the roles of the financial intermediaries in the financial systems. The theory establishes that the contribution of intermediaries is to ensure steady flow of the funds from the surplus unit to the deficit units. The role of financial intermediaries is essential in that it ensures the growth of the economy through supply of financial commodities (Scholten and Wensveen, 2003). The financial intermediaries ensure the creation of a platform that enables transaction of different commodities. The financial intermediaries exist due to the market imperfections. As such, in perfect market situations, with no transaction or information costs, financial intermediaries would not have existed. Numerous financial markets are characterized by informational differences between buyers and sellers.

Furthermore, the financial intermediary theory analyzes the functions and roles of financial intermediaries in the economy, the way in which the financial intermediation influences the economy on the whole and the effects of government policies on financial intermediaries. Most of the studies performed highlight their roles in achieving a durable economic growth, and the impact of regulations on financial intermediation, accentuating the role of regulatory authorities in the supervision and control of financial intermediaries.

The financial intermediation theory is based on the assumption of the presence of informational asymmetry and the agency theory. In principle, the existence of financial intermediaries is explained by the existence of the following categories of factors: high cost of transaction, lack of complete information in useful time; and the method of regulation. In financial markets, information asymmetries are particularly pronounced. Investors tend to borrow with the collateral and entrepreneurs have inside information about their own investment seeking financing. It explains the importance of intermediation process of financial intermediaries in the economy as a whole.

ECRTD-UK: https://www.eajournals.org/

ULR: https://doi.org/10.37745/ejaafr.2013 
In support of the financial intermediary theory, Shittu (2012) emphasized that intermediaries eliminate (or reduce) the need for self-financing of investments. In particular, by providing liquidity, financial institutions permit risk averse savers to hold deposits rather than liquid (but unproductive) assets. The funds obtained by the deposit money banks are then available for investment in productive capital. Hence, deposit money banks should finance any positive net present value project if the cost of investment is below the expected returns

The financial intermediation theory is criticized on the ground that it is heavily focused on the functions of financial institutions that are no longer crucial in mature financial systems. Also the emphasis of financial intermediation theory on the role of intermediaries as reducing the frictions of transaction costs and asymmetric information is too strong; while these factors may once have been central to the role of intermediaries, they are increasingly less relevant. Shittu (2012) suggested a view on financial intermediaries that centers on two roles. First, they are the facilitators of risk transfer and deal with an increasingly complex maze of financial instruments and markets. The key area of intermediary activity therefore has become risk management, whereas traditional intermediation theory offers little to explain why institutions should perform this function.

The financial intermediation theory is relevant to this study as it emphasizes the functions of deposit money banks in mobilizing, channeling, pooling savings and increasing investment levels in the economy, thus improving their efficiency and expanding their functions through technological innovation contributes immensely to the growth of the economy.

\section{Theoretical Framework}

This study reviewed two theories in the literature. These theories Silber's Constraint Theory of Innovation and Financial intermediation theory. Considering the determinants of technological innovation adoption and banking operations of deposit money banks in Nigeria, this study focused on Silber's Constraint Theory of Innovation and Financial Intermediation Theory. These theories are of the opinion that adoptions of technological innovations in the banking sector tend to attract more customers to banks product, saves the bank in huge administrative cost and also improves the operational efficiencies of deposit money banks. Also, the theories postulate that deposit money banks basically provide payment mechanism which is part of their financial intermediation function. Therefore, the payment mechanism function of deposit money banks can be improved through adoption of technologically enabled process. Moreover, through harnessing the power of technology, banks can enhance efficiency which in turn leads to cost reduction.

\section{Empirical Review}

\section{Ease of use of technological innovations and operational efficiency}

Nwankwo, Phillip and Abomeh (2015) examined the impact technological innovations on the performance of deposit money banks in Nigeria between the periods 2006 to 2015. The log-linear regression model was used to test the impact of various forms of technological innovations on the banks operational efficiency and return on equity (ROE), the computation of the result was done using the econometric computer software package, e-view version 8.0. The result showed that the

ECRTD-UK: https://www.eajournals.org/

ULR: https://doi.org/10.37745/ejaafr.2013 
adoption of various forms of technological innovations has greatly influenced the quality of banking operations, performance and has specifically increased banks' operational efficiency and return on equity. The study recommended that investment in technological innovations should form an important component in the overall strategy of banking operation, as these will make Nigerian banks to be more efficient, profitable and competitive.

Monyoncho (2015) investigated the relationship between E-Banking technologies and financial performance of commercial banks in Kenya. The study population included all 44 commercial banks licensed by Central Bank of Kenya. Secondary data for a five years period were collected from financial statements of commercial banks in line with the specific variables of the study. Regression analysis was conducted to establish the nature of the relationship. The study revealed that ATM innovations offer financial institutions the opportunity to transform the ATM from a cash dispenser to a customer relationship management tool, helping to enhance loyalty among all customers. Credit cards are being adopted by the banks so as to increase income, and to reduce credit and liquidity risks. Mobile banking is likely to have major impacts on the profitability of commercial banks as business operations get smoothen and that internet banking offers the convenience of conducting most of the banking transactions at a time that suits the customer.

Akhisar and Tunay (2015) examined the effect of technological innovations on bank's performance in Turkey. The study adopted a descriptive research design where secondary data was collected from twenty-three countries. The study assessed the effect of credit cards, debit cards, point of sales, ATMs and internet banking on the performance of selected banks measured by operational efficiencies. The findings revealed that both POS and internet banking had a negative effect on operational efficiencies of banks in Turkey. On the contrary, the ratio of ATMs to bank branches had positive effect on operational efficiencies of the selected banks. The study concluded that ATMs are beneficial to banks since they improve performance.

Kamau and Oluoch (2016) employed the correlation research design to examine the causal effect of innovation on commercial banks operational efficiencies from 2012 to 2015. Purposive sampling was used to select eleven (11) commercial banks which are listed and actively trading in NSE. Secondary data was collected from the published annual reports for commercial banks spanning four years from 2012 to 2015. Descriptive statistics showed the average commercial banks performance was $23.7 \%$. Correlation analysis showed that ATM banking had the highest influence on commercial bank operational efficiencies and more ATM and banking services should be availed to customers. Regression analysis showed that ATM, mobile banking, use of credit and debit cards, internet banking and agency banking all have positive significant influence on commercial banks' performance in Kenya.

Dabor, Ezie and Anyatonwu (2017) studied the effect of technological innovation adoption on the operational performance of banks in an emerging economy. The study adopted both inferential and descriptive design using a t-test, the findings of the study revealed that a positive relationship exists between technological innovation and operational performance of deposit money banks in

ECRTD-UK: https://www.eajournals.org/

ULR: https://doi.org/10.37745/ejaafr.2013 
Nigeria. This implies that a marginal change in the level of the investment and adoption of technological innovations such as (Automated teller machine, Web based transactions, and Mobile payments) in the banking industry resulted in a proportionate increase in the banks operational performance. The study recommended that it is paramount for bank management to intensify investment in technological products to facilitate speed, convenience, and accurate service delivery.

Ibeta and Anyanwu (2017) evaluated the relationship between technological innovation and bank efficiency as well as the impact of financial innovation on efficiency ratio of deposit money banks in Nigeria from 2006 to 2014. The secondary data covering the period of the study were sourced from the Central Bank of Nigeria statistical bulletin. The unit root test was performed to ensure that the variables were free from stationarity defect linked with almost all time series data due to the nature they were generated. A multiple regression model was developed and estimated to evaluate the relationship among the variables concerned. The finding reveals that the value of transaction on Automated Teller Machine (ATM) and Point of Sale (POS) are negatively related with efficiency ratio while web/internet and mobile banking are positively related but only that of web/internet was significantly related. The granger impact assessment depicts that financial innovation products reflected by value of transaction on ATMs, web/internet, POS and mobile banking has no significant impact on efficiency ratio of deposit money banks in Nigeria. However, we found evidence that banks' efficiency ratio exerted statistically significant impact on value of transactions on ATMs. In view of the findings, the study recommended that banks should invest more in ATMs and POS platforms as it reduces the operating expenses to net income ratio while ensuring effective utilization of existing web/internet and mobile banking infrastructure rather than acquiring new ones that will gulp a large fraction of their net operating income. Web/internet and mobile banking should be redesigned in such a way that customization will enable customers access all the banking services which would indeed reduce its transaction costs.

\section{Compatibility of technology and operational structure}

Raymond, Ibuathu and Simon (2011) carried out a study to determine the influence of technological innovation in terms of compatibility of technology on operational performance and operational structure of commercial banks in Meru town. The study employed the descriptive research design. The total population was 60 members of management staff in commercial banks branches that operate in Meru town and the study adopted a census sample design. Data was collected using a questionnaire approach, descriptive and inferential analyses were used to analyze data. The study found that financial performance and operational structure of commercial banks' branches in Meru towns is positively influenced by innovation. This implies that innovations adoption by commercial banks presents a high potential for the enhancement of financial performance therefore yielding increased returns for the shareholders. The study also noted that innovations versatility has resulted to their increased adoption rate among the banks and customers Gakure and Ngumi (2013) established the effects of credit cards, mobile banking, internet banking and agency banking on the financial performance and operational structure of commercial banks in Kenya. The population of the study consisted of forty four commercial banks that are currently

ECRTD-UK: https://www.eajournals.org/

ULR: https://doi.org/10.37745/ejaafr.2013 
operating in Kenya, The target population was sixteen banks and at least four members of the management team with representations in the following dimensions; locally incorporated banks, banks incorporated elsewhere but operating in Kenya, banks in which the government has some shareholding and also based on size. Secondary data was collected from the banks for the periods 2008 to 2012. The study found that some banks in Kenya had adopted some financial innovations such as credit cards, mobile, internet and agency banking. The financial innovations had great impact on the financial performance and operational structure of the selected banks.

Makur (2014) assessed the effect of financial innovation on commercial bank's financial performance in the banking sector over a period of five (5) years in South Sudan. The study used a casual research methodology and studied sixteen (16) commercial banks registered with the central bank of South Sudan from 2009 to 2013. The findings indicated that return on asset (ROA) recorded a mean of 3.2534 with standard deviation of 1.2548. The average number of daily transactions using ATM for the commercial banks during the study period was 156,547 with standard deviation of 20,51. The study also revealed that adoption of financial innovation resulted in strong operational structures of commercial banks in South Sudan.

Cherotich and Sang (2015) examined the effect of financial innovations on operational structure of commercial banks in Kenya. The study relied on secondary data. It adopted a census where all the forty-four (44) banks were used in the study and there was no sampling since the population size was small. The study found out that there is a strong relationship between financial innovations and operational structure of deposit money banks. The study concludes that financial innovations positively affect financial performance.

Gichungu and Oloko (2015) studied the effect of mobile phone banking, ATM banking, online banking and agency banking on the financial performance of commercial banks in Kenya. The target population of this study was all the forty-three (43) commercial banks in Kenya. The study was based on secondary data which was collected from the published annual reports for commercial banks spanning five years (2009-2013) during which technological innovations have been intensely invested in by banks. Multiple regression analysis was used to test the relationship between bank innovations and financial performance among commercial banks in Kenya. In addition, the Pearson Product Moment Correlation Coefficient was used to test the direction and magnitude of the relationship between the dependent and independent variables at $95 \%$ confidence level and 5\% level of significance. The study established that the identified bank innovations, precisely, mobile phone banking, online banking, agency banking and ATM banking had positively impacted on the financial performance of commercial banks in Kenya over the 5 year period between 2009 and 2013.

\section{METHODOLOGY}

The cross-sectional survey research design was adopted for this study. This was carried out using primary data through the use of questionnaire. Through this design, the use of questionnaire is

ECRTD-UK: https://www.eajournals.org/

ULR: https://doi.org/10.37745/ejaafr.2013 
considered appropriate as a method of retrieving information for data collection and classification. The study considered the views of respondents from the selected deposit money banks in Lagos State, Nigeria. The justification for using survey research design was based on its capability for collecting enormous data; it is also useful in describing the characteristics of a large population extensively.

\section{Population}

The target population for this research comprised of deposit money banks in Nigeria. The selected banks include; United Bank for Africa (UBA), First Bank Nigeria Plc, Wema bank, Guaranty Trust Bank Plc (GTBank) Zenith Bank Plc, First City Monument Bank (FCMB) and Access Bank Plc. The total population of respondents which comprised of customers profiled of e-channels platforms. The total population in this category is 2,358 customers from the selected deposit money banks (NIBSS, 2016).

\section{Sample size and sampling Technique}

In order to collect an unbiased sample for the study and because this study is targeted at employees and customers of the selected deposit money banks in Lagos State, a random sampling technique was employed for the study so as to give all respondents an equal chance of being represented in the study. The objective of research work is to draw inference from the sample of the population in order to make generalizations on the whole population. However, because of the large population involved in most studies, researchers hardly study the entire population. Therefore, sample will be drawn from the study population from the banks in Lagos State. The researcher adopted Yaro Yamane formula to determine the sample size. Thus, the sample size was derived using the formula below;

$\mathrm{n}=\frac{\mathrm{N}}{1+\mathrm{N}\left(\mathrm{e}^{2}\right)}$

Where:

$\mathrm{n}=$ appropriate sample size

$\mathrm{N}=$ population size

$\mathrm{e}=$ co-efficient or confidence margin or error unit

$\mathrm{e}=$ error of $5 \%$

Thus, the sample size is calculated as;

$$
\begin{aligned}
& \mathrm{n}=\frac{2358}{1+2358\left(0.05^{2}\right)} \\
& \mathrm{n}=\frac{\frac{2358}{1+124.7525}}{\mathrm{n}}=\frac{2358}{125.7525} \\
& \mathrm{n}=140
\end{aligned}
$$

ECRTD-UK: https://www.eajournals.org/

ULR: https://doi.org/10.37745/ejaafr.2013 


$$
\mathrm{n}=140
$$

To this end therefore, 140 respondents would constitute the sample size for this research study.

\section{Research Instrument}

The research instrument is a device for collecting the data or measuring the variable which are used for answering research questions and/or testing hypothesis. The research instrument that was used for this study is an adopted semi structured questionnaire. A questionnaire is a document that consists of a set of leading questions which logically are arranged and are to be filled by the respondent himself. Semi-structured questionnaires will be adopted since they offer the researcher an opportunity to collect both structured and unstructured data. This is important in research since standardized data makes it easy to conduct analysis and to draw inferences, while at the same time, open ended questions offered respondents opportunity to clarify their answers in the structured section (Cooper \& Schindler, 2014). The questionnaire was divided into three parts. Part 1 covers demographic factors, while parts 2 and 3 covers independent and dependent variable consecutively.

The research instrument designed for this study is a 5-point Likert scale questionnaire aimed at eliciting the respondent's perception of the effect of technological innovations in banking operations among the DMBs.

\section{Validity of the Instrument}

Validation of instrument is the extent to which an instrument measures what it is supposed to measure and performs as it is designed to perform. Validity is defined as the ability of a scale or measuring instrument to measure what is intended to be measured (Kothari, 2004) A content validity will be used for the study. Content validity is a process of justifying a questionnaire through its contents and variables. The questionnaire was submitted to the researcher's supervisor, a research statistician and a specialist in the field of research for verification and correction in order to establish an accurate criterion of the validity of the instrument and all necessary corrections were made before the questionnaire was administered.

\section{Model Specification}

The model in this study followed the study of Ibeta and Anyanwu (2017) where they examined the effects of technological innovations on operations of deposit money banks in Nigeria. Taking cognizance of their models, the model for this study was modified with respect to the objectives of the study and given as:

$\mathrm{Y}=\mathrm{f}(\mathrm{X})$

$\mathrm{X}=$ Technological Innovation Adoption

$\mathrm{Y}=$ Banking Operations

$\mathrm{X}=\left(\mathrm{x}_{1}, \mathrm{X}_{2}\right)$

$\mathrm{Y}=\left(\mathrm{y}_{1}, \mathrm{y}_{2}\right)$

\section{Sub-Variables for $\mathrm{X}$ are;}

$\mathrm{x}_{1}=$ Ease of Use (EU)

ECRTD-UK: https://www.eajournals.org/

ULR: https://doi.org/10.37745/ejaafr.2013 
$\mathrm{x}_{2}=$ Compatibility $(\mathrm{CM})$

Sub-Variables for $\mathrm{Y}$ are;

$\mathrm{y}_{1}=$ Operational Efficiency $(\mathrm{OE})$

$\mathrm{y}_{2}=$ Operational Structure $(\mathrm{OS})$

\section{Functional Relationship}

$\mathrm{OE}=\mathrm{f}(\mathrm{EU})$ (Model 1)

$\mathrm{OS}=\mathrm{f}(\mathrm{CM})$ (Model 2)

\section{Model Specification}

All the models was tested using primary data

$\mathrm{OE}=\beta_{0}+\beta_{1} \mathrm{EU}_{\mathrm{i}}+\mu_{1}$

$\mathrm{OS}=\beta_{0}+\beta_{1} \mathrm{CM}_{\mathrm{i}}+\mu$

$\beta_{0}=$ Intercept

$\beta_{1}=$ Coefficients

$\mu_{1}=$ error term

\section{RESULT AND DISCUSSION}

\section{Descriptive Analysis}

The hypotheses of the study were tested using simple regression analysis to show the cause-effect between the variables and significance of the study was taken at $5 \%$ level of significance.

\section{Table 1 Distribution of Questionnaire}

\begin{tabular}{|l|l|l|}
\hline & $\begin{array}{l}\text { Frequency } \\
\text { N }\end{array}$ & $\begin{array}{l}\text { Percentage (\%) } \\
\text { \% }\end{array}$ \\
\hline Returned and duly completed & 110 & 96.1 \\
\hline Unreturned & 30 & 3.9 \\
\hline Total & 140 & 100.0 \\
\hline
\end{tabular}

\section{Source: Field Survey, 2020}

Table 1 showed that 140 questionnaires were distributed out of which 110 copies of the questionnaires were return and 30 copies were not returned. The returned questionnaires amounts to $96.1 \%$ of the total distributed questionnaires while $3.9 \%$ mirrors the questionnaires that were unreturned. The unreturned questionnaires must have either been misplaced or may not have been filled correctly which made it very fit to be discarded. However, the discarded questionnaires were constituted the questionnaires that were not included in the study.

ECRTD-UK: https://www.eajournals.org/

ULR: https://doi.org/10.37745/ejaafr.2013 
European Journal of Accounting, Auditing and Finance Research

Vol.10, No. 1, pp.25-54, 2022

Print ISSN: 2053-4086(Print),

Online ISSN: 2053-4094(Online)

Table 2 Percentage Distribution of the Respondents by Socio-Demographic Characteristics

\begin{tabular}{|c|c|c|}
\hline & Frequency & Percent (\%) \\
\hline \multicolumn{3}{|l|}{ Age } \\
\hline $18-25$ & 35 & 31.8 \\
\hline $26-35$ & 43 & 39.1 \\
\hline $36-59$ & 32 & 29.1 \\
\hline 60years and above & 0 & 0 \\
\hline Total & 110 & 100.0 \\
\hline \multicolumn{3}{|l|}{ Gender } \\
\hline Male & 56 & 50.9 \\
\hline Female & 54 & 49.1 \\
\hline Total & 110 & 100.0 \\
\hline \multicolumn{3}{|l|}{ Marital Status } \\
\hline Single & 42 & 38.2 \\
\hline Married & 39 & 35.5 \\
\hline Others & 29 & 26.4 \\
\hline Total & 110 & 100.0 \\
\hline \multicolumn{3}{|c|}{ Years of Banking Experience } \\
\hline 1 & 34 & 30.9 \\
\hline 2 & 28 & 25.5 \\
\hline $3-5$ & 35 & 31.8 \\
\hline 6 and above & 13 & 11.8 \\
\hline Total & 110 & 100.0 \\
\hline \multicolumn{3}{|l|}{ Department } \\
\hline Customer Service & 19 & 17.3 \\
\hline Operations & 23 & 20.9 \\
\hline Internal Control & 29 & 26.4 \\
\hline Marketing & 39 & 35.5 \\
\hline Total & 110 & 100.0 \\
\hline \multicolumn{3}{|l|}{\begin{tabular}{|l|} 
Educational Level \\
\end{tabular}} \\
\hline Primary & 1 & 0.9 \\
\hline Secondary & 3 & 2.7 \\
\hline Tertiary & 53 & 48.2 \\
\hline Others & 53 & 48.2 \\
\hline Total & 110 & 100 \\
\hline \multicolumn{3}{|c|}{\begin{tabular}{|l|} 
Professional Qualifications \\
\end{tabular}} \\
\hline ACA & 0 & 0 \\
\hline ACIB & 20 & 18.2 \\
\hline $\mathrm{ACS}$ & 30 & 27.3 \\
\hline $\mathrm{ACCA}$ & 18 & 16.4 \\
\hline Others & 42 & 38.2 \\
\hline Total & 110 & 100 \\
\hline
\end{tabular}

Source: Field Survey, 2020

\section{Interpretation}

Table 2 above shows that $31.8 \%$ of the respondents were between ages $18-25,39.1 \%$ of the respondents were between the ages of $26-35$ years, $25.1 \%$ of the respondents were between the

ECRTD-UK: https://www.eajournals.org/

ULR: https://doi.org/10.37745/ejaafr.2013 
ages of 36-59. However, majority of the respondents were between the ages of 26-35 years, this implies that the bulk of the employees of deposit money banks in Lagos State were more of age bracket that would understand better the usefulness, benefit and implications of digital banking convenience on customers' satisfaction. The result of the analysis on Table 2 also reveals that $50.9 \%$ of the respondents were male while $49.1 \%$ of them were female. Table 2 depicts that most of the respondents were married (48.2\%) with the singles having a percentage of $35.5 \%$ and $26.4 \%$ of the respondent were respondents with other category of marital status some of which might be divorced, widow or widower and or separated. Also, the finding on Table 2 reveals that $30.9 \%$ of the respondents had 1 year experience of banking operations, $25.5 \%$ of the respondents had 2 years' experience, $31.8 \%$ of the respondents had 3-5 years of working experience and $11.8 \%$ of the respondents had an experience of 6 years and above. This shows that majority of the respondents had 3-5 years of working experience and can give optimum answers that can be trusted for this analysis.

Furthermore, Table 2 shows that $17.3 \%$ of the respondents were in customer service department, $20.9 \%$ of the respondents were in the operations department, $26.4 \%$ of the respondents were internal control officers and $35.5 \%$ of the respondents were in marketing department. The findings show that majority of the respondents were in operations department implying that the outcome and results of this study on the effect of technological innovation on banking operation would be well examined and information would be adequately collected. Table 2 above also shows that most of the respondents $(48.2 \%)$ have an educational level of tertiary and others (M.Sc and Ph.D) educational level. According to table 2, 18.2\% of the respondents have the professional qualification of ACIB, $27.3 \%$ of the respondents has ACS qualifications, $16.4 \%$ of the respondents has ACCA qualification and $38.2 \%$ of the respondents has other qualifications with no respondents having the qualification of ACA.

\section{Analysis of Respondents Responses}

This section discusses the frequency of respondents' responses to each of the questions classified according to the research variables together with their specific percentage. The analysis is done as follows;

ECRTD-UK: https://www.eajournals.org/

ULR: https://doi.org/10.37745/ejaafr.2013 
Vol.10, No. 1, pp.25-54, 2022

Print ISSN: 2053-4086(Print),

Online ISSN: 2053-4094(Online)

Table 3

Ease of Use

\begin{tabular}{|c|c|c|c|c|c|c|c|c|}
\hline Ease of Use & SA & $\mathbf{A}$ & UD & D & SD & NA & Mean & $\begin{array}{l}\text { Std. } \\
\text { Dev. }\end{array}$ \\
\hline $\begin{array}{l}\text { Technology recently } \\
\text { deployed by the bank is } \\
\text { easy to use by me }\end{array}$ & $\begin{array}{l}69 \\
(62.7 \%)\end{array}$ & $33(30.0 \%)$ & $7(6.4 \%)$ & $1(0.9 \%)$ & $0(0.0 \%)$ & $0(0.0 \%)$ & 4.5455 & \\
\hline $\begin{array}{l}\text { There are teething } \\
\text { issues which arose from } \\
\text { technology and } \\
\text { application deployed } \\
\text { by the Bank which } \\
\text { made it not easy to use }\end{array}$ & $48(43.6 \%)$ & $45(40.9 \%)$ & $15(13.6 \%)$ & $2(1.8 \%)$ & $0[0.0]$ & $0(0.0 \%)$ & 4.2636 & \\
\hline $\begin{array}{l}\text { The technology and } \\
\text { application deployed } \\
\text { are user-friendly }\end{array}$ & $55(50.0 \%)$ & $51(46.4 \%)$ & $4(3.6 \%)$ & $0(0.0 \%)$ & $0(0.0 \%)$ & $0(0.0 \%)$ & 4.4636 & \\
\hline $\begin{array}{l}\text { It is only someone with } \\
\text { vast experience in } \\
\text { Computer that can use } \\
\text { the deployed } \\
\text { technology in and } \\
\text { applications in the bank }\end{array}$ & $51(46.4 \%)$ & $55(50.0 \%)$ & $4(3.6 \%)$ & $0(0.0 \%)$ & $0(0.0 \%)$ & $0(0 . \%)$ & 4.4273 & \\
\hline $\begin{array}{l}\text { I don't find it } \\
\text { complicated using bank } \\
\text { technology }\end{array}$ & $54(49.1 \%)$ & $53(42.2 \%)$ & $3(2.7 \%)$ & $0(0.0 \%)$ & $0(0.0 \%)$ & $0(0.0 \%)$ & 4.4636 & \\
\hline
\end{tabular}

\section{Source: Field Survey, 2020}

\section{Interpretation}

Table 3 shows that $62.7 \%$ of the respondents strongly agreed that technology recently deployed by the bank is easy to use by them, $30.0 \%$ agreed to the notion, $6.4 \%$ of the respondents were indecisive, $0.9 \%$ of the respondents disagreed, $0 \%$ of the respondents strongly disagreed and none of the respondents view that the statement on technology recently deployed by the bank is easy to use by them is not applicable. The mean of the responses which is 4.5455 showed that most of the respondents agreed that technology recently deployed by the bank is easy to use by them. The standard deviation of 0.555 further buttressed this assertion.

$43.6 \%$ of the respondents strongly agreed that there are teething issues which arose from technology and application deployed by the banks which made it not easy to use, $40.9 \%$ of the respondents agreed to the notion, $13.6 \%$ of the respondents did not decide on the notion, $1.8 \%$ of the respondents disagreed, $0.0 \%$ respondents strongly disagreed and none of the respondents believed that the statement is applicable. From the mean value of 4.2636, it can be concluded that on the average, the respondents were agreed that there are teething issues which arose from technology and application deployed by the banks which made it not easy to use. The standard deviation of 0.728 also affirms this claim.

ECRTD-UK: https://www.eajournals.org/

ULR: https://doi.org/10.37745/ejaafr.2013 
Furthermore, Table 3 showed that $50.0 \%$ of the respondents strongly agreed that the technology and application deployed are user-friendly, $46.4 \%$ of the respondents agreed to the view, $3.6 \%$ of the respondents were those who neither agreed nor disagreed on the view, none of the respondents disagreed that the technology and application deployed are user-friendly, while none of the respondents strongly disagreed. The mean value of 4.4636 suggests that most of the respondents agreed that the technology and application deployed are user-friendly. The standard deviation value of 0.553 further confirms this claim.

Also, $46.4 \%$ of the respondents strongly agreed that it is only someone with vast experience in computer that can use the deployed technology and applications in the bank while 50.0\% of the respondents agreed to the notion, $3.6 \%$ of them were indecisive, none of the respondents disagreed or strongly disagreed on the view and none of the respondents were of the view that the statement is not applicable. On the average however, the mean of the respondents of 4.4273 suggests that most of the respondents were agreed that it is only someone with vast experience in computer that can use the deployed technology and applications in the bank. The standard deviation of 0.885 also affirms this position.

Table also reveal that $49.1 \%$ of the respondents strongly agreed that I don't find it complicated using bank technology while $42.2 \%$ of the respondents agreed to the notion, $2.7 \%$ of them were indecisive on the notion, none of the respondents disagreed or strongly disagreed on the view and none of the respondents were of the view that the statement is not applicable. On the average however, the mean of the respondents of 4.3646 suggests that most of the respondents agreed that I don't find it complicated using bank technology. The standard deviation of 0.865 also affirms this notion.

Table 4 Measure of Technological Innovations (Compatibility)

\begin{tabular}{|c|c|c|c|c|c|c|c|c|}
\hline Compatibility & SA & $\mathbf{A}$ & UD & D & SD & NA & Mean & Std. Dev. \\
\hline $\begin{array}{l}\text { The bank services is } \\
\text { well suited to meet } \\
\text { the needs of various } \\
\text { customers }\end{array}$ & $57(51.8 \%)$ & $50(45.5 \%)$ & $3(2.7 \%)$ & $0(0.0 \%)$ & $0(0.0 \%)$ & $0(0.0 \%)$ & & \\
\hline 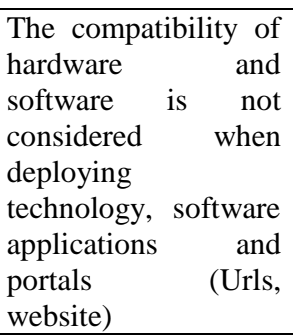 & $50(45.5 \%)$ & $53(48.2 \%)$ & $7(6.4 \%)$ & $0(0.0 \%)$ & $0(0.0 \%)$ & $0(0.0 \%)$ & 2.85 & 1.561 \\
\hline $\begin{array}{l}\text { I can use any of my } \\
\text { mobile and computer } \\
\text { system to access the } \\
\text { bank services }\end{array}$ & $49(44.5 \%)$ & $58(52.7 \%)$ & $3(2.7 \%)$ & $0(0.0 \%)$ & $0(0.0 \%)$ & $0(0.0 \%)$ & 2.74 & 0.174 \\
\hline
\end{tabular}

ECRTD-UK: https://www.eajournals.org/

ULR: https://doi.org/10.37745/ejaafr.2013 
Online ISSN: 2053-4094(Online)

\begin{tabular}{|l|l|l|l|l|l|l|l|l|}
\hline $\begin{array}{l}\text { I rarely encounter } \\
\text { operational when } \\
\text { difficulties when } \\
\text { using the applications }\end{array}$ & $50(45.5 \%)$ & $57(51.8 \%)$ & $3(2.7 \%)$ & $0(0.0 \%)$ & $0(0.0 \%)$ & $0(0.0 \%)$ & 2.88 & 1.772 \\
\hline $\begin{array}{l}\text { I don't experience } \\
\text { hitches and failure } \\
\text { when processing } \\
\text { transactions for } \\
\text { customers on the } \\
\text { deployed application }\end{array}$ & $40(36.4 \%)$ & $66(60.0 \%)$ & $4(3.6 \%)$ & $0(0.0 \%)$ & $0(0.0 \%)$ & $0(0.0 \%)$ & 2.78 & 1.709 \\
\hline
\end{tabular}

Source: Field Survey, 2020

\section{Interpretation}

Table 4 shows that $51.8 \%$ of the respondents strongly agreed that the bank services is well suited to meet the needs of various customers, $45.5 \%$ of the respondents agreed to the view, $2.7 \%$ were respondents could not make decision towards the notion The bank services is well suited to meet the needs of various customers, none of the respondents disagreed or strongly disagreed to the notion, likewise none of the respondents were of the view that the notion is not applicable. Considering the mean value of 4.835 and standard deviation of 0.561 , it can therefore be said that on the average, virtually all the respondents agreed that The bank services is well suited to meet the needs of various customers.

In the same vein, Table 4 depicts that $45.5 \%$ of the respondents strongly agreed that the compatibility of hardware and software is not considered when deploying technology, software applications and portals (Urls, website), $48.2 \%$ of the respondents agreed to the view, $6.4 \%$ of the respondents were indecisive, none of the respondents disagreed or strongly disagreed or strongly disagreed and none of the respondents believed that the view not applicable. With this, and considering the mean value of 4.724 and standard deviation of 0.174 , it can therefore be said that on the average, most of the respondent agreed that the compatibility of hardware and software is not considered when deploying technology, software applications and portals (Urls, website).

Table 4 also depicts that $44.5 \%$ of the respondents strongly agreed that they can use any of their mobile and computer system to access the bank services, $52.7 \%$ of the respondents agreed, $2.7 \%$ of the respondents were indecisive on the notion, none of the respondents disagreed or strongly disagreed, while none of the respondents believed that the view is not applicable. With this, and considering the mean value of 4.274 and standard deviation of 0.174 , it can therefore be said that on the average, most of the respondent agreed that I can use any of my mobile and computer system to access the bank services.

Furthermore, Table 4 reveals that $45.5 \%$ of the respondents strongly agreed that they rarely encounter operational difficulties when using the applications, $51.8 \%$ of the respondents agreed to the view, $2.7 \%$ of the respondents were indecisive on the opinion that they rarely encounter operational difficulties when using the applications, none of the respondents disagreed and none of respondents strongly disagreed with none of the respondents believing that the opinion is not

ECRTD-UK: https://www.eajournals.org/

ULR: https://doi.org/10.37745/ejaafr.2013 
applicable. Examining the mean value of 4.828 and standard deviation of 0.772 , it can therefore be concluded that on the average, most of the respondent agreed that they rarely encounter operational difficulties when using the applications.

Table 4 reveals that $36.4 \%$ of the respondents strongly agreed that they do not experience hitches and failure when processing transactions for customers on the deployed application, $60.0 \%$ of the respondents agreed, $3.6 \%$ of the respondents were indecisive, none of the respondents disagreed or strongly disagreed and none of the respondents were of the opinion that the view of the statement above is not applicable to the view. The mean and standard deviation values of 2.78 and 1.709 respectively shows that respondents do not experience hitches and failure when processing transactions for customers on the deployed application.

Table 5 Measure of Banking Operations (Operational Efficiency)

\begin{tabular}{|l|l|l|l|l|l|l|l|l|}
\hline Operational Efficiency & SA & A & U & D & SD & NA & Mean & $\begin{array}{l}\text { Std. } \\
\text { Dev. }\end{array}$ \\
\hline $\begin{array}{l}\text { I do not experience sudden } \\
\text { errors in any transactions } \\
\text { within and outside the bank } \\
\text { operating offices }\end{array}$ & $\begin{array}{l}54(49 . \\
1 \%)\end{array}$ & $\begin{array}{l}49(44 . \\
5 \%)\end{array}$ & $7(6.4 \%)$ & $\begin{array}{l}0(0.0 \\
\%)\end{array}$ & $\begin{array}{l}0(0.0 \\
\%)\end{array}$ & $\begin{array}{l}0(0.0 \\
\%)\end{array}$ & 4.36 & 2.018 \\
\hline $\begin{array}{l}\text { There is an improvement in } \\
\text { the quality of services the } \\
\text { bank renders to his } \\
\text { customers }\end{array}$ & $\begin{array}{l}55(50 . \\
0 \%)\end{array}$ & $\begin{array}{l}50(45 . \\
5 \%)\end{array}$ & $5(4.5 \%)$ & $\begin{array}{l}0(0.0 \\
\%)\end{array}$ & $\begin{array}{l}0(0.0 \\
\%)\end{array}$ & $0(0.0$ & 3.26 & 1.716 \\
\hline $\begin{array}{l}\text { There is a reduction in the } \\
\text { level of customer compliant } \\
\text { and experience on all the } \\
\text { banks platforms }\end{array}$ & $\begin{array}{l}57(51 . \\
8 \%)\end{array}$ & $\begin{array}{l}47(42 . \\
7 \%)\end{array}$ & $6(5.5 \%)$ & $\begin{array}{l}0(0.0 \\
\%)\end{array}$ & $\begin{array}{l}0(0.0 \\
\%)\end{array}$ & $\begin{array}{l}0(0.0 \\
\%)\end{array}$ & 2.98 & 1.607 \\
\hline
\end{tabular}

\section{Source: Field Survey, 2020}

\section{Interpretation}

From Table 5 above, it reveals that $49.1 \%$ of the respondents strongly agreed that the website for digital banking has a lead and format that make it easy to use, $44.5 \%$ of the respondents agreed to the view, $6.4 \%$ of the respondents were indecisive, none of the respondents disagreed or strongly disagreed and none of the respondents believed that it is not applicable that the website for digital banking has a lead and format that make it easy to use. It can therefore be said based on the mean value of 4.36 that most of the respondents disagreed that the website for digital banking has a lead and format that make it easy to use. The standard deviation of 2.018 also affirms this.

$50.0 \%$ of the respondents strongly agreed that there is an improvement in the quality of services the bank renders to his customers, $45.5 \%$ agreed to the view, $4.5 \%$ of the respondents did not decide on the view, with none of the respondents disagreed or strongly disagreed to this notion,

ECRTD-UK: https://www.eajournals.org/

ULR: https://doi.org/10.37745/ejaafr.2013 
and none of the respondents believed that the view is not applicable. It can therefore be said based on the mean value of 3.26 and standard deviation of 1.716 that most of the respondents agreed that there is an improvement in the quality of services the bank renders to his customers.

In the same direction, Table 5 shows that $51.8 \%$ of the respondents strongly agreed that there is a reduction in the level of customer compliant and experience on all the banks platforms, $42.7 \%$ of the respondents agreed, $6.5 \%$ of the respondents were indecisive to this notion, but none of the respondents disagreed or strongly disagreed to the view, and none of the respondent believed that their view is not applicable. Therefore, it can be concluded based on the mean value of 2.98 and standard deviation of 1.607 that on the average, most of the respondents agreed that there is a reduction in the level of customer compliant and experience on all the banks platforms.

Table 6 Measure of Banking Operations (Operational Structure)

\begin{tabular}{|l|l|l|l|l|l|l|l|l|}
\hline Operational Structure & SA & A & U & D & SD & NA & Mean & $\begin{array}{l}\text { Std. } \\
\text { Dev. }\end{array}$ \\
\hline $\begin{array}{l}\text { There is ease of reconciliation } \\
\text { with settlement banks }\end{array}$ & $\begin{array}{l}50(45.5 \\
\%)\end{array}$ & $\begin{array}{l}56(5 \\
0.9 \% \\
)\end{array}$ & $\begin{array}{l}4(3.6 \% \\
)\end{array}$ & $\begin{array}{l}0(0.0 \\
\%)\end{array}$ & $\begin{array}{l}0(0.0 \\
\%)\end{array}$ & $0(0.0 \%$ & 3.36 & 1.622 \\
\hline $\begin{array}{l}\text { Customer complaints from } \\
\text { dissatisfaction with e-platform } \\
\text { applications has resulted into } \\
\text { litigation and discourage } \\
\text { further use of the delivery } \\
\text { channel }\end{array}$ & $\begin{array}{l}51(46.4 \\
\%)\end{array}$ & $\begin{array}{l}53(4 \\
8.2 \% \\
)\end{array}$ & $\begin{array}{l}6(5.5 \% \\
)\end{array}$ & $\begin{array}{l}0(0.0 \\
\%)\end{array}$ & $\begin{array}{l}0(0.0 \\
\%)\end{array}$ & $0(0.0 \%$ & 3.87 & 1.661 \\
\hline $\begin{array}{l}\text { There are no significant } \\
\text { hindrances involved in the } \\
\text { bank operations }\end{array}$ & $\begin{array}{l}55(50.0 \\
\%)\end{array}$ & $\begin{array}{l}51(4 \\
6.4 \% \\
)\end{array}$ & $\begin{array}{l}4(3.6 \% \\
)\end{array}$ & $\begin{array}{l}0(0.0 \\
\%)\end{array}$ & $\begin{array}{l}0(0.0 \\
\%)\end{array}$ & $0(0.0 \%$ & 3.54 & 1.330 \\
\hline $\begin{array}{l}\text { All the bank electronic } \\
\text { platform is always available } \\
\text { and reliable all the time }\end{array}$ & $\begin{array}{l}54(49.1 \\
\%)\end{array}$ & $\begin{array}{l}50(4 \\
5.5 \%\end{array}$ & $\begin{array}{l}6(5.5 \% \\
)\end{array}$ & $\begin{array}{l}0(0.0 \\
\%)\end{array}$ & $\begin{array}{l}0(0.0 \\
\%)\end{array}$ & $0(0.0 \%$ & 3.47 & 1.476 \\
\hline
\end{tabular}

Source: Field Survey, 2020

\section{Interpretation}

Table 6 depicts that $45.5 \%$ of the respondents strongly agreed that there is ease of reconciliation with settlement banks, $50.9 \%$ of the respondents agreed, $3.6 \%$ of the respondents neither agreed nor disagreed, none of the respondents disagreed or strongly disagreed and also none of the respondents were opinion that the view on if there is ease of reconciliation with settlement banks is not applicable. It can therefore be said based on the mean value of 3.36 that most of the respondent agreed that they feel secure while processing transaction through the deployed technology. The standard deviation of 1.622 also affirms this.

ECRTD-UK: https://www.eajournals.org/

ULR: https://doi.org/10.37745/ejaafr.2013 
Also, Table 6 above reveals that $46.4 \%$ strongly agreed that customer complaints from dissatisfaction with e-platform applications has resulted into litigation and discourage further use of the delivery channel, $48.2 \%$ of the respondents agreed, $5.5 \%$ were indecisive, but none of the respondents disagreed or strongly disagreed and none of the respondents believed that it is not applicable. It can therefore be said based on the mean value of 3.87 and standard deviation of 1.661 that most of the respondent disagreed that they feel secure while making transaction through the internet.

Table 6 shows that $50.0 \%$ of the respondents strongly agreed that there are no significant hindrances involved in the bank operations, $46.4 \%$ of the respondents agreed to the notion, 3.6\% of the respondents were indecisive, none of the respondents disagreed or strongly disagreed to the notion and none of the respondents were of the point that the view above is applicable. Therefore, it can be concluded based on the mean value of 3.54 and standard deviation of 1.330 that on the average, most of the respondents disagreed that there are no significant hindrances involved in the bank operations.

Lastly, $49.1 \%$ of the respondents strongly agreed that all the bank electronic platform are always available and reliable all the time, $45.5 \%$ of the respondents agreed, that all the bank electronic platform are always available and reliable all the time, 5.5\% were indecisive with none of the respondents disagreed or strongly disagreed to the notion and none believed that it is not applicable. It can therefore be concluded based on the mean value of 3.47 and standard deviation of 1.476 that most the respondents disagreed that they feel secure while making transaction through the internet.

\section{Test of Hypothesis One (Ho1)}

Research Objective One: Determine how ease of use of technological innovations affects operational efficiency of deposit money banks in Lagos, Nigeria.

Research Question One: How does ease of use of technological innovations affect operational efficiency of deposit money banks in Lagos, Nigeria?

Research Hypothesis One (Ho1): Ease of use of technological innovations has no significant effect on operational efficiency of deposit money banks in Lagos, Nigeria.

Table $7 \quad$ Regression Estimate on Operational Efficiency

\begin{tabular}{|l|l|l|l|l|}
\hline \multirow{2}{*}{ Variable } & \multicolumn{4}{|c|}{ Model 1 } \\
\cline { 2 - 5 } & Coefficient & Std Error & t-Stat. & Prob. \\
\hline $\mathbf{C}$ & 2.652 & 0.328 & 8.085 & $0.000^{*}$ \\
\hline EU & 0.408 & 0.078 & 5.250 & $0.000^{*}$ \\
\hline $\mathbf{R}^{2}$ & 0.179 & & \\
\hline Adjusted R & & & \\
\hline S.E of Reg & 0.173 & & \\
\hline F-Statistic & 6.053 & & \\
\hline Prob.(F-Stat) & 27.559 & & \\
\hline Obs & $0.000^{*}$ & & \\
\hline
\end{tabular}

Source: Researcher's Study, 2020

*significance at $\mathbf{5 \%}$

Dependent Variable: Operational Efficiency

ECRTD-UK: https://www.eajournals.org/

ULR: https://doi.org/10.37745/ejaafr.2013 


\author{
Model 1 \\ $\mathbf{O E}_{\mathrm{i}}=\alpha_{1}+\beta_{1} \mathrm{EU}_{\mathrm{i}}+\mu_{1}$ \\ $\mathbf{O E}_{\mathrm{i}}=2.652+0.4083 \mathrm{EU}_{\mathrm{i}}$
}

\title{
Interpretation
}

Hypothesis one of this study examined the effect of ease of use on operational efficiency of deposit money banks in Lagos, Nigeria. In fulfillment of the objective one, research question one and hypothesis one of this study, ease of use was used as independent variable while operational efficiency was used as dependent variable. Observable in the result presented above, the independent variable (ease of use) employed was examined and decisions was made using the $\mathrm{p}$ values of the results. Considering the signs and magnitude of the estimated parameters, the values of the coefficient of ease of use is negative. A unit change in ease of use will increase the operational efficiency by 0.408 . The value of the constant implies that if the independent variable employed does not exist, operational efficiency will maintain a positive value of 2.652.

The adjusted $\mathrm{R}^{2}$ value of $17.3 \%$ for ease of use reassured the ability of the independent variables to collectively explain any variation in the dependent variable up to these numbers of percentage even if the observations and variables are infinitely enlarged. The explanatory power of the regression model with an adjusted $\mathrm{R}^{2}$ of 0.173 is impressive. This implies that there is good fit of the model, showing that there is a positive relationship between the regressors (independent variables) and the regressed (dependent variable).

The t-statistics showed the individual significance of the variables in the model. From the above presented result, ease of use have significant effect on the operational efficiency at $5 \%$ level of significance. The F-statistics measured the overall performance of the model employed in the study. The F-statistics value for this study is 27.559. The significance of this variable is ascertained using the p-values. From the results the p-value for ease of use is less than 0.05. Considering this, this study shows that ease of use has significant effect on operational efficiency.

At a level of significance 0.05 , the F-Statistics is 27.559 , while the p-value of the F-Statistics is 0.000 which is less than 0.05 adopted, the study therefore rejected the null hypothesis which means that ease of use significantly affect operational efficiency of the selected banks in this study.

\section{Test of Hypothesis Two (H02)}

Research Objective Two: Examine the effect of compatibility of technological innovations on operational structure of deposit money banks in Lagos, Nigeria.

Research Question Two: What is the effect of compatibility of technological innovations on operational structure of deposit money banks in Lagos, Nigeria?

Research Hypothesis Two (Ho2): Compatibility of technological innovations has no significant effect on operational structure of deposit money banks in Lagos, Nigeria?

ECRTD-UK: https://www.eajournals.org/

ULR: https://doi.org/10.37745/ejaafr.2013 
Online ISSN: 2053-4094(Online)

Table 8 Regression Estimate on Operational Structure
\begin{tabular}{|l|l|l|l|l|}
\hline Variable & Model 2 & Prob. \\
\cline { 2 - 5 } & Coefficient & Std Error & t-Stat. & 0.000 \\
\hline C & 2.052 & 0.286 & 7.175 & \\
\hline CM & 0.556 & 0.068 & 8.143 & 0.000 \\
\hline$R^{2}$ & 0.345 & & & \\
\hline Adjusted R & 0.340 & & \\
\hline S.E of Reg & 11.629 & & \\
\hline F-Statistic & 66.312 & & \\
\hline Prob.(F-Stat) & $0.000^{*}$ & & \\
\hline Obs & 110 & & \\
\hline
\end{tabular}

Source: Researcher's Study, 2020 *significance at $5 \%$

\section{Model 2}

Dependent Variable: Operational Structure

$\mathrm{OS}_{\mathrm{i}}=\alpha_{1}+\beta_{1} \mathrm{CM}_{\mathrm{i}}+\mu_{1}$

$\mathrm{OS}_{\mathrm{i}}=2.052+0.556 \mathrm{CM}_{\mathrm{i}}$

\section{Interpretation}

Hypothesis two of this study examined the effect of compatibility of technological innovations on operational structure of deposit money banks in Lagos, Nigeria. In fulfillment of the objective two, research question two and hypothesis two of this study, compatibility was used as independent variable while the operational structure was used as dependent variable. Observable in the result presented above, the independent variable employed was examined and decisions were made using the p-values of the results. Considering the signs and magnitude of the estimated parameters, the values of the coefficient of compatibility is positive. A unit change in compatibility will increase the relevance of operational structure by 0.556 . The value of the constant imply that if the independent variables employed do not exist, the relevance of financial reporting quality will maintain a positive value of 2.052 .

The adjusted $\mathrm{R}^{2}$ value of $34 \%$ for compatibility reassured the ability of the independent variable to collectively explain any variation in the dependent variable up to these numbers of percentage even if the observations and variables are infinitely enlarged. The explanatory power of the regression model with an adjusted $R^{2}$ of 0.340 is impressive. This implies that there is good fit of the model, showing that there is a very strong positive relationship between the regressors (independent variables) and the regressed (dependent variable).

The t-statistics reflected the individual significance of the variables in the model. From the above presented result, compatibility have significant effect on the relevance of operational structure at $5 \%$ level of significance. The F-statistics measured the overall performance of the model employed in the study. The F-statistics value for this study is 66.312. The significance of this variable is ascertained using the p-values. From the results above, all the p-value for compatibility is less than

ECRTD-UK: https://www.eajournals.org/

ULR: https://doi.org/10.37745/ejaafr.2013 
0.05 . Considering this, this study shows that compatibility have significant effect on operational structure of deposit money banks.

At a level of significance 0.05 , the F-Statistics is 66.312 , while the p-value of the F-Statistics is 0.000 which is less than 0.05 adopted, the study therefore rejected the null hypothesis which means that compatibility significantly affect operational structure of deposit money banks in Nigeria.

\section{DISCUSSION OF FINDINGS}

This study examined the determinants of technological innovation adoption and its effect on banking operations of deposit money banks in Nigeria. The peculiarity of this study affords the chronological presentation of this chapter.

The study revealed that majority of the respondents is between the age brackets of 26-35 years. The group of population in this age category is $39.1 \%$ of the total respondents. These groups of respondents are those in their early adult age and could give details on the effect of technological innovations on banking operations of deposit money banks in Lagos, Nigeria. Hence, it can be said that the questionnaires distributed are filled by well-informed respondents; thus, their opinion can be trusted. The table also shows that majority of the respondents are male, given that $49.1 \%$ of the total respondents were males. It also shows that majority of the respondents are married constituting about $48.2 \%$ of the respondents. Also, the number of years of respondents working experience shows that majority of the respondents had between 3-5 years of working experience, which can help give trustable answers to the questionnaire. In the same vein, it shows that the most of the respondents of this study are found in the marketing department. They account for a total percentage of $52.5 \%$ of the total respondents.

The regression estimate of model 1 shows that ease of use significantly affects operational efficiency of the selected Banks in this study. This result is inconsistence with the a priori expectation that there is no significant impact of ease of use on the operational efficiency of Nigeria deposit money banks. The result was corroborated by the probability value of the $F$ statistics of 0.000 which shows that the regression result is statistically significant because this is less than $5 \%$, the level of significant adopted for this study. This implies that ease of use thus impacts on operational efficiency of the selected Nigeria money banks. The findings of this study is consistent with the study of Adesola, Moradeyo and Oyeniyi (2013) where they concluded that ease of use of technological innovations have a positive and significant effect on operational efficiencies of deposit money banks.

The regression estimate of model 2 shows that compatibility significantly affects operational structure of the selected deposit money banks in Nigeria. This result is inconsistence with the $a$ priori expectation that there is no significant effect of compatibility on operational structure of deposit money banks in Nigeria. The result was also corroborated by the probability of the $F$ statistics 0.000 which shows that the regression result is statistically significant because this is less

ECRTD-UK: https://www.eajournals.org/

ULR: https://doi.org/10.37745/ejaafr.2013 
than 5\%, the level of significant adopted for this study. This implies that compatibility thus affect the operational structure of the selected deposit money banks positively. The findings of this study is consistent with the study of Dauda (2018), who in his study confirmed that compatibility of technological innovations with users specification helps operational structure and management of banks.

\section{CONCLUSION}

Findings of this study therefore provide insight into the effect of technological innovations on Banking Operations which has been measured by Operational Efficiency (OE) and Operational Structure (OS) of selected money banks in Nigeria. It also provides an affirmation of the extent to which the variations in the dependent variable are caused by the independent variables covered in the models as depicted by the R-squared and adjusted R-squared.

The use of technological innovation shows that there is increase in the operations of deposit money banks in Nigeria and it increases the confidence of customers towards Nigerian banking industry. From responses obtained from employees and customers on technological innovations and how it affects banking operations of deposit money banks; it showed that it has increased customers loyalty to banks in general. This study indicated that almost all the banking services under consideration affect the banking operations of the banks in Nigeria. However, the number of POS terminals and the number of customer using internet banking service are determined to affect the operations of the banks. This situation can be interpreted as the sample had differences in electronic banking positively. Thus, the research concluded that technological innovations have a significant effect on banking operations of the selected deposit money banks in Lagos, Nigeria.

\section{RECOMMENDATIONS}

- $\quad$ Central Bank of Nigeria should organize seminars, workshops, symposia and public lectures to bank customers and general public on the application of information and technology cum e-banking system. This will aid to increase the use of various e-banking products in Nigeria especially in this era of cashless economy drive.

- $\quad$ Government through CBN should provide adequate security measures towards the various e-banking products in Nigeria. This will aid in reducing the rate of fraud and forgery in the banking industry and encourage investors which in turn will increase the banks' cash inflow cum use of available fund for granting of credit facilities.

- Deposit money banks in Nigeria should regularly train their employees who in turn will educate their customers on electronic banking system and its products. This will enhance the indepth understanding of the products and the way they are being used. Hence, more customers cum deposits will be attracted.

ECRTD-UK: https://www.eajournals.org/

ULR: https://doi.org/10.37745/ejaafr.2013 
European Journal of Accounting, Auditing and Finance Research

Vol.10, No. 1, pp.25-54, 2022

Print ISSN: 2053-4086(Print),

Online ISSN: 2053-4094(Online)

\section{REFERENCES}

Adegbie, F. \& Dada, O. (2018). Risk asset management, liquidity management and sustainable performance of Nigeria Deposit Money Banks. International Journal of Accounting Research, 6(2), 2-10

Adesola, M., Moradeyo, O. \& Oyeniyi, K. (2013). Information communication technology adoption and financial markets in Africa. Journal of Accounting and Management, 4(1), 65-79.

Akerlof, B. C. \& Girardone, D. E. (2011). The impact of electronic banking on the performance of banks. Journal of internet banking and commerce, 16(2), 101-120.

Akhisar, I. \& Tunanay, N. (2015). Effects off innovation on bank performance. Journal of Social and Behavioural Sciences, 1(2), 67-84.

Bananuka, J., Tumwebaze, Z. \& Orobia, L. A. (2018). The adoption of integrated reporting: A developing country perspective. Journal of Financial Reporting and Accounting. 2(2), 1154.

Black, B. (2011). The non-correlation between board independence and long term firm performance. Romanian Economics Journal, 14(39), 61-87.

Casu, B., Girardone, C., \& Molyneux, P. (2006). Introduction to banking. England: Prentice hall Press.

Chen, M. (2005). Managerial optimism and corporate investment in Taiwan. Pacific Basin Finance Journal, 1(2), 43-75.

Cheriotich, A. \& Sang, J. (2015). A general equilibrium model of a multi-firm moral hazard economics in financial markets. Journal of Mathematical Finance, 2(2), 76-90.

Cytonn, K. (2016). Market Outlook Report on internet banking adoptions. Journal of Business and Management,20(2), 82-91.

Cumming, D. (2008). Contracts and exits in venture capital finance. Review of Financial Studies 5(2), 76-89.

Dabor, A., Ezie, F. \& Anyatonwu, C. (2017). Technological innovation and financial performance of banks. Journal of Business, Economics, Financial Science and Management, 5(1), 205224.

Damanpour, F. (2010). Managerial innovation, conceptions and processes. Journal of operational management, 1(1), 43-61.

Dauda, Y. (2018). Technological change and employee performance in selected manufacturing industry in Nigeria. Australian Journal of Business and Management Sciences, 5(1), 87102.

Davila, A., Epstein, M. \& Stretton, B. (2010). Do Internet activities add value? Evidence from traditional banks. Journal of Financial Services Research, 4 (6), 105-120.

Drucker, P. (2013). Empirical studies of innovation activity. Interdisciplinary Journal of Contemporary Research in Business, 4(1), 2162-3082.

Eriksson, K. (2008). The adoption of commercial innovations in the former central and eastern European markets. International Journal of Banking and Finance, 8(3), 55-76.

Gakure, R. \& Ngumi, A. (2013). Bank innovation and profitability of commercial banks in Kenya. Prime Journal of Social Sciences, 5(3), 88-96.

ECRTD-UK: https://www.eajournals.org/

ULR: https://doi.org/10.37745/ejaafr.2013 
Gichungu, Z. \& Oloko, M. (2015). Relationship between bank innovations and financial performance of commercial banks in Kenya. International Journal of Education and Research, 1(2), 56-87.

Husein, S. (2013). Online corporate social responsibility disclosure in the Gulf cooperation countries. Review of Accounting and Finance, 1(2), 90-103.

Ibeta, A. \& Anyanwu, F. (2017). Distrust determinants of mobile banking adoption in the Nigerian banking industry. The Asian Journal of Technological Management, 2(2), 110-122.

Kabuye, F., Kato, J., Akugizibwe, I. \& Bugambiro, N. (2019). Internal control systems, working capital management and financial performance of supermarkets. Journal of Business \& Management Science, 6(1), 15-73.

Kamau, D. \& Ouoch, J. (2016). Relationship between financial innovation and commercial banks performance in Kenya. International Journal of Social Sciences and Management Research, 1(2), 16-25.

Khalil, S. (2012). Power of collateral in securing transaction limited private credit for moveable property. The Arabian Journal of Technological Management, 2(2), 110-122.

Levine, R. (2000). Finance and sources of growth. Journal of Financial Economics, 1(3), 65-91.

Makur, M. (2014). The effects of financial innovation on the financial performance of commercial banks in South Sudan. Research Journal of Finance and Accounting ,7(19), 65-76.

Monyoncho, L. (2015). Relationship between banking technologies and financial performance of commercial banks in Kenya. International Journal of Economics, Commerce and Business Research, 1(2), 54-67.

Nalukenge, I., Nkundabanyanga, S. K. \& Ntayi, J. M. (2018). Corporate governance, ethics, internal controls and compliance with IFRS. Journal of Financial Reporting and Accounting, 16(4), 764-786.

Ngugi, K. \& Karina, B. (2013). Effect of innovation strategy on performance of commercial banks in Kenya. International Journal of Social Sciences Research, 4(1), 231-256.

Nwankwo, N., Philip, C. \& Abomeh, A. (2015). Factors that influence the acceptance of mobile money in Nigeria. Journal of Research in Marketing, 7(1), 65-79.

Obasan, K. (2011). Management information system as a catalyst to organizational performance in the $21^{\text {st }}$ century of selected banks in Nigeria. American Journal of Business Research, 1(2), 37-69.

Obeng, Y. \& Mkhize, P. (2017). Impact of information system strategy on technological innovation strategic alignment on firm performance. International Journal of Information Technology, 3(1), 67-87.

OECD. (2005). Adoption of technological innovation in the banking industry. Quarterly Finance Review, 56-90.

Oke, A. \& Goffin, K. (2011). Technology adoption and consumer payments: Evidence from survey data. Review of Network Economic, 2(2), 45-62.

Parasuraman, A. (2010). Service productivity, quality and innovation. International Journal of Quality and Service, 5(3), 99-115.

Raymond, A., Ibuathu, M. \& Simon, A. (2011). Technological innovations and financial performance of banks. Asian Journal of Empirical Research, 15, 132-141.

ECRTD-UK: https://www.eajournals.org/

ULR: https://doi.org/10.37745/ejaafr.2013 
European Journal of Accounting, Auditing and Finance Research

Vol.10, No. 1, pp.25-54, 2022

Print ISSN: 2053-4086(Print),

Online ISSN: 2053-4094(Online)

Sahem A. N. (2015). The Effect of information technology on the bank profitability Empirical Study of Jordanian Banks. International Journal of Business and Management, 10(2), 1833-3850.

Scholten, B. \& Wensveen, D. (2003). A critique on the theory of financial intermediation. Journal of Monetary Economics, 17(2), 271-291.

Shawk, A. (2008). Evaluation of the determinants of operational efficiencies in banks. International Journal of Economics and Finance, 4(2), 98-114.

Shittu, I. (2012). Financial intermediation and economic growth in Nigeria. British Journal of Arts and Social Sciences, 4(2), 164-179.

Ssekiziyivu, B., Mwesigwa, R., Joseph, M. \& Nkote, I. (2017). Credit allocation, risk management and loan portfolio performance of MFIs: A case of Ugandan firms. African Journal of Economic Review, 5(2), 109-115.

Vjayasarathy, A. (2004). Predicting consumer intentions to use online shopping: The case of an augmented technology acceptance model. Journal of Information Management, 6(3), 105119.

Yaw, A. \& Boachie, E. (2018). The impact of IT-technological innovation on the productivity of bank's employee. Journal of Cogent Business \& Management, 5(12), 122-152.

Yinus, A. \& Waidi, A. (2011). Technological change and employees' performance. Australian Journal of Business Management, 1(2), 66-87.

ECRTD-UK: https://www.eajournals.org/

ULR: https://doi.org/10.37745/ejaafr.2013 